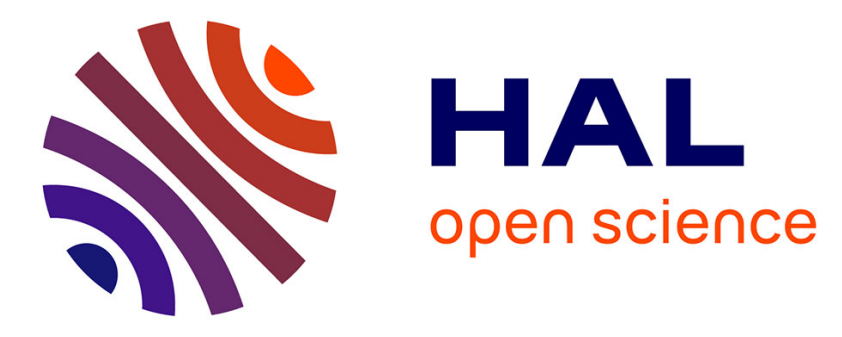

\title{
How to manage plant biomass originated from phytotechnologies? Gathering perceptions from end-users
}

Valérie Bert, Silke Neu, Isabelle Zdanevitch, Wolfgang Friesl-Hanl, Serge Collet, Rodolphe Gaucher, Markus Puschenreiter, Ingo Muller, Jurate Kumpiene

\section{To cite this version:}

Valérie Bert, Silke Neu, Isabelle Zdanevitch, Wolfgang Friesl-Hanl, Serge Collet, et al.. How to manage plant biomass originated from phytotechnologies? Gathering perceptions from end-users. International Journal of Phytoremediation, 2017, 19 (10), pp.947-954. 10.1080/15226514.2017.1303814 . ineris-01863194

\section{HAL Id: ineris-01863194 \\ https://hal-ineris.archives-ouvertes.fr/ineris-01863194}

Submitted on 28 Aug 2018

HAL is a multi-disciplinary open access archive for the deposit and dissemination of scientific research documents, whether they are published or not. The documents may come from teaching and research institutions in France or abroad, or from public or private research centers.
L'archive ouverte pluridisciplinaire HAL, est destinée au dépôt et à la diffusion de documents scientifiques de niveau recherche, publiés ou non, émanant des établissements d'enseignement et de recherche français ou étrangers, des laboratoires publics ou privés. 


\section{ACCEPTED MANUSCRIPT}

International Journal of Phytoremediation

Standard research article

Title: How to manage plant biomass originated from phytotechnologies? Gathering perceptions from end-users.

V. Bert ${ }^{\mathrm{a},}$, , S. Neu ${ }^{\mathrm{b}}$, I. Zdanevitch ${ }^{\mathrm{a}}$, W. Friesl-Hanl ${ }^{\mathrm{c}}$, S. Collet ${ }^{\mathrm{d}}$, R. Gaucher ${ }^{\mathrm{a}}$, M. Puschenreiter ${ }^{\mathrm{e}}$, I. Müller $^{\mathrm{f}}$, J. Kumpiene ${ }^{\mathrm{g}}$

${ }^{a}$ INERIS, Clean and Sustainable Technologies and Processes Unit, DRC/RISK, Parc Technologique Alata, BP2, 60550 Verneuil en Halatte, France

${ }^{\mathrm{b}}$ Technische Universität Dresden, Institute of Wood and Plant Chemistry, D-01737 Tharandt, Germany

${ }^{c}$ AIT Austrian Institute of Technology GmbH, Energy Department, A-3430 Tulln, Austria ${ }^{\mathrm{d}}$ INERIS, Sources and Emissions Unit, DRC/CARA, Parc Technologique Alata, 60550 Verneuil en Halatte, France

${ }^{e}$ University of Natural Resources and Life Sciences Vienna - BOKU, Department of Forest and Soil Sciences, Konrad-Lorenz-Straße 24, A-3430 Tulln, Austria

${ }^{\mathrm{f}}$ Saxon State Agency for Environment, Agriculture and Geology, D-01109 Dresden, Germany

${ }^{g}$ Waste Science and Technology, Luleå University of Technology, 97187 Luleå, Sweden

*Corresponding author. INERIS, Clean and Sustainable Technologies and Processes Unit, DRC/RISK, Parc Technologique Alata, BP2, 60550 Verneuil en Halatte, France. E-mail address: valerie.bert@ineris.fr(V. Bert), tel: + 333445563 82, fax: + 33344556556. 


\section{ACCEPTED MANUSCRIPT}

\section{Abstract}

A questionnaire survey was carried out in 4 European countries to gather end-user's perceptions of using plants from phytotechnologies in combustion and anaerobic digestion (AD). 9 actors of the wood energy sector from France, Germany and Sweden, and 11 AD platform operators from France, Germany and Austria were interviewed. Questions related to installation, input materials, performed analyses, phytostabilization and phytoextraction. Although the majority of respondents did not know phytotechnologies, results suggested that plant biomass from phytomanaged areas could be used in $\mathrm{AD}$ and combustion, under certain conditions. As a potential advantage, these plants would not compete with plants grown on agricultural lands, contaminated lands being not suitable for agriculture production. Main limitations would be related to additional controls in process' inputs and end-products and installations that might generate additional costs. In most cases, price of phytotechnologies biomass was mentioned as a driver to potentially use plants from metal-contaminated soils. Plants used in phytostabilisation or phytoexclusion were thought to be less risky and, consequently, benefited from a better theoretical acceptance than those issued from phytoextraction. Results were discussed according to national regulations. One issue related to the regulatory gap concerning the status of the plant biomass produced on contaminated land.

Keywords: soil contamination, combustion, anaerobic digestion, trace elements, phytostabilisation, phytoextraction 


\section{ACCEPTED MANUSCRIPT}

\section{Introduction}

Production of energy crops, although welcomed from the renewable energy perspective, has become considered as a threat to food security and even to sustainable development. ${ }^{1,2}$ Finding alternative sites for energy crop cultivation would eliminate these risks. Marginalised land due to low fertility and contamination could provide areas for energy cultures without competing with agricultural land. By this, synergistic benefits could be achieved: increased production of renewable energy, encouraged by the Renewable Energy Directive (RED) ${ }^{2}$; as well as restoration of degraded land using phytotechnologies. Phytotechnologies, plant-based options for contaminated land management, often assisted by beneficial microorganisms and soil amendments not only provide valuable sources of renewable biomass for the bio-based-economy (e.g. bioenergy, biocatalysis and platform molecules for green chemicals, and ecomaterials), but also improve ecosystem services by restoring soil structure, quality and functions. ${ }^{3}$

A number of plant species have an ability to grow on contaminated soil without developing toxicity symptoms or accumulating elevated concentrations of trace elements (TE) in their above-ground tissues. Therefore, elevated concentrations of TE in soil do not necessary lead to the higher concentrations of these TE in the harvestable biomass. However, some plant species can extract considerably more TE from soil than the average physiological levels and lead to accumulation of TE in their aboveground parts. This means that depending on the choice of plants and the aim of the phytotechnology (i.e. (aided) phytostabilization vs phytoextraction) harvested biomass can have different levels of TE. Nevertheless, all plants can be considered as raw materials for the bio-based-economy if (i) TE do not disturb the functioning and the 


\section{ACCEPTED MANUSCRIPT}

performance of the biomass processing, (ii) if the TE transfer is controlled and impacts on the environment are prevented; and (iii) if such plant use complies with current regulation.

Among the different valuation pathways, biomass can be converted to bioenergy via physical, biological and thermal processes. Combustion is the most important energy conversion way for biomass to produce heat and electricity. Combustion results in bottom ashes and flue gases (gaseous fraction and fly ashes). Combustion of metal-enriched woody biomass resulting from phytotechnologies was recently explored at pilot scale regarding the fate of metals in emissions and associated regulatory aspects. ${ }^{4,5}$ Highest concentrations of $\mathrm{Cd}$ and $\mathrm{Zn}$ were found in fly ash compared to bottom ash. From these studies, the combustion of metal enriched poplars and willows in boilers equipped with efficient filters is recommended to minimize air pollution and comply with regulatory thresholds. Anaerobic digestion (AD) leads to formation of digestate and biogas, the latest being used either to produce heat and electricity or as a transport fuel, or injected into the natural gas distribution network. The biogas sector has been expanding in Europe over the past few years as recently reported. ${ }^{6}$ Since only a few studies discussed the possibility to use phytoremediating plant biomass in $\mathrm{AD}$, the information related to the fate of metals and their influence on anaerobic performance are rare. ${ }^{7-15}$ The application of ashes and digestate resulting from the conversion of phytoremediating plants on soil for agricultural purposes could be potentially problematic. It will depend on the quality of residues, notably their metal content and the existing legal frameworks.

To our knowledge, perception of operators of biomass conversion pathways and regulation issues in the context of phytotechnologies have been little studied so far, whereas for a successful 


\section{ACCEPTED MANUSCRIPT}

deployment these technologies must be acceptable from a technical, regulatory and social point of view. $^{16,4}$

In this work, we reported the opinions of a panel of operators of two routine biomass conversion pathways, combustion and $\mathrm{AD}$, concerning the possibility to accept plant biomass produced on phytomanaged areas in their installations. Perceptions, in terms of potential advantages and limitations, of 19 operators from France, Germany, Sweden and Austria were collected through a questionnaire performed during the course of the European project GREENLAND. Results of the questionnaires were confronted with the current regulations of the 4 countries involved in the study. Due to the small number of interviews and the limited geographic outreach of interviews, the results of the study are not reproducible and transposed to

other countries. By integrating technical, regulatory and social aspects, our objective was to help to identify relevant valorization pathways for the plant biomass produced by phytostabilization and phytoextraction.

\section{Materials and Methods}

A questionnaire survey was carried out during the European "GREENLAND” project (http://www.greenland-project.eu/, 2011-2014) to gather actors opinions for assessing potential limitations and advantages regarding technical, economical and regulatory aspects of using plants from phytotechnologies in combustion and AD installations. Two questionnaires were designed, one specifically for combustion and another one for $\mathrm{AD}$, each containing four different sections as follows: (i) installation characteristics (e.g. size of the digester, temperature of AD, 


\section{ACCEPTED MANUSCRIPT}

type of furnace, nominal thermal power), (ii) input material characteristics (e.g. type of plant used, annual plant proportion in the installation, mixture of input materials), (iii) constraints on input materials (e.g. origin, regulatory or voluntary constraints on metal concentrations in input materials) and (iv) questions related to the participant's awareness of phytotechnologies. Section (i) included questions related to air emission cleaning system and end-products (digestate, leachate, ashes, gases) treatments and valuations. Figure S1 shows part of the section on phytotechnologies.

Participants that used wood and energy crops as fuel/feedstocks at a significant rate in combustion and $\mathrm{AD}$ (boiler and $\mathrm{AD}$ platforms operators/owners) were selected from partner countries of the GREENLAND project. The questionnaire survey was carried out between 2012 and 2014 resulting in 9 interviews of actors of the wood energy sector from France (4), Germany (2) and Sweden (3), and 11 interviews of AD platforms operators from France (5), Germany (4) and Austria (2). Table 1 summarizes the main characteristics of participating installations and input materials.

Participating AD installations were mainly isolated farms or farm groupings (Table 1) that provided themselves with input materials produced on or adjacent to the farm $(<10 \mathrm{~km})$. Temperature of $\mathrm{AD}$ process ranged from 38 to $55^{\circ} \mathrm{C}$ and lasted from 21 to 160 days. Biogas produced by such $\mathrm{AD}$ installations was used to heat on-site digester and buildings, produce hot water and dry agricultural products. Biogas was also used to produce electricity injected into the national power network, upgraded to be injected into the natural gas grid or used as a transport fuel (Table 1). All respondents entirely valorized the produced digestate by direct spreading on 


\section{ACCEPTED MANUSCRIPT}

farmland with or without application plan, as a structuring matter to produce compost or both (Table 1). Input materials were very diverse as shown in Table 1.

Participants to the combustion survey were mainly municipal or private wood boilers (Table 1). Both in Sweden and France, each interviewed municipality had a municipality-owned company that operates the boiler. In Germany, one large boiler was operated by a private company. In addition, a French company that operates boilers of various sizes, a French boiler wood supplier and a German farm grouping from a rural district were interviewed (Table 1). Input fuels were mainly wood (Table 1) coming from local or regional forest (6 out of 9 respondents) or from wood trade companies (4 out of 9 respondents), two respondents being supplied with wood waste. The gases generated by the combustion are used to produce heat (all respondents) and electricity (one respondent) (Table 1). Ashes are differently valuated according to the country. In Sweden, ashes are typically valorized by direct spreading in forests or mixing with construction materials, whereas in France and Germany ashes can be valuated in agriculture (composting, direct spreading) or disposed off on landfills (Table 1).

\section{Results and Discussion}

\subsection{Feedback from the questionnaire survey on AD}

\subsubsection{Input materials}

In $\mathrm{AD}$ platforms, plants resulting from home garden green waste, parks and gardens, agricultural wastes or dedicated cultures (e.g. maize, sunflower) were used as substrate injected in the digester or added as a structuring matter to make compost (Table 2). When several plants were used in the $\mathrm{AD}$ process, these were mixed together to increase the $\mathrm{AD}$ performance. 


\section{ACCEPTED MANUSCRIPT}

In France, installations are exclusively dedicated to $\mathrm{AD}$ of non-hazardous waste or crude plant material (Table S3) ${ }^{17}$ Legally, cultivation of energy crops (dedicated culture) is prohibited because of land-use competition for food, unless it is intermediate cropping for AD feedstock, i.e. the arable land is all year covered with plant culture in rotation, among which one cropping is harvested in between and used to feed the farm AD unit. The large variety of plants used in the French AD platforms is the result of this political framework (Table 2).

In Germany, suitable input materials are listed in a positive list as part of the quality assurance system for digestate which is a voluntary system. ${ }^{18}$ Conversely to France, Germany has opted in the past to develop agricultural $\mathrm{AD}$ facilities by encouraging the planting of energy crops (Table 2). As German respondents reported, input materials derived from renewable energy crops included manure, energy crops (e.g. maize silage, grass silage, whole plant grain silage, cereal grain, sugar beet, Sudan grass) and diversified materials, like green-waste from landscaping and straw (Table 2). When the questionnaire survey was carried out, the $\mathrm{AD}$ operators were subjected to the Renewable Energy Sources Act of 2012 (EEG 2012) which explicitly encouraged the use of energy crops by additional reimbursements (Table S3) $\cdot{ }^{19}$ This political framework led to the use of mainly maize in almost $80 \%$ of the German agricultural AD plants. ${ }^{20}$ In contrast to ref. 19, the current EEG 2014 does not encourage the use of energy crops with high additional remuneration anymore but promotes the use of residual materials instead like manure and biowaste. ${ }^{21}$

In Austria, $300 \mathrm{AD}$ units existed by the end of 2015 on a farm level or small farmer cooperations with the feedstock (maize, grass, manure) available in close proximity to most plants. ${ }^{22}$ The Austrian government recognizes that crops for $\mathrm{AD}$ can be grown as part of a 


\section{ACCEPTED MANUSCRIPT}

normal agricultural rotation or on land that is not suitable for food crops, and that some crops may need to be added to slurry-based AD to ensure efficient operation (Table S3). Consequently, most of AD plants are installed in grasslands instead of arable lands, i.e. areas that do not compete with food production. Crops, such as grasses and maize, can be used as the sole feedstock for AD, or combined with others (Table 2). Grass comes usually from residual grasslands in mainly agricultural regions.

Concerning the questions related to potential analyses and preparation of input materials, most of respondents indicated to perform qualitative and quantitative analyses to ensure AD performance (Table S4). Qualitative analyses were performed to avoid problems due to physical impurities (e.g. plastic). Quantitative analyses were performed according to feedstock quality management and mostly relied on organic content, dry matter and biogas yield (Table S4). All respondents indicated that contaminants (e.g. metals, PAHs) content in input materials was not a concern and consequently input materials were not analyzed for such compounds. Indeed, most of respondents knew the origin of the input materials and assumed that they were free of contaminants.

\subsubsection{Output / digestate valorization}

However, contaminants, in particular metals, became a concern for those respondents who directly spread the produced digestate on farmland. In this case, annual (or pluri-annual) metal analyses of soil were performed before digestate spreading to check the suitability with the metal thresholds set in national regulatory framework (e.g. for France, ${ }^{23}$ ) (Tables S3 and S5). In 


\section{ACCEPTED MANUSCRIPT}

addition, when the digestate is composted, the produced compost has to comply with metal thresholds set in national standards (e.g. for France, ${ }^{24,25}$ ) (Tables S3 and S5).

In France, digestate can only be spread as a soil improver or fertilizer on arable lands of the farm that produced it, after characterization (e.g. agronomic value, amount, production yield) and annual application plan (Table S3). ${ }^{26}$ Otherwise, it has to be composted following the French quality standard on soil improvers which states agronomic requirements and, notably, threshold values for metals (Table S5). ${ }^{24}$ In addition to metal limit, the compost standard gives fixed maximum heavy metal load (Table S5).

In Germany, digestate can be produced from biowastes, from renewable energy crops, from manure, or from a mixture of those (Table S3). Land application by direct spreading of digestate on farm is allowed and common practice (Table S3). Composting of digestate is possible and promoted on or outside farmland (Table S3). ${ }^{19}$ Quality criteria for digestate products concerns, among others, heavy metal concentrations. Digestate resulting from agricultural, horticultural or forestry production is regarded as a fertiliser and has to comply with the limits set in the fertiliser ordinance whereas digestate made partly or totally with biowastes has to comply with the biowaste ordinance limits. ${ }^{27,28}$ Table S5 shows the limits set for metals in these regulations.

In Austria, land application by direct spreading of digestate on farm is allowed and usual, whereas composting of digestate is of minor importance (Table S3). When it is done, it falls under the compost regulation. Digestates produced from pure agricultural products, i.e. not wastes (e.g. maize, grass), from organic waste materials (e.g. old oil, fat, leftovers) or both are allowed to be spread on agricultural land if criteria from the fertiliser ordinance (DMV) are met 


\section{ACCEPTED MANUSCRIPT}

(Table S5). ${ }^{29}$ In addition, the Compost Ordinance which specifies clear quality standards for composts has to be considered when digestate is made of biowastes and agricultural products. ${ }^{30}$ According to this Ordinance, compost is classified into three quality classes, depending on the heavy metal concentrations. The metal limits regulate compost application for organic farming (Class A+), agriculture and hobby gardening (Class A) or landscaping and reclamation (Class B) (Table S5).

On EU-level, the EU ECO label for soil improver promotes the production and reuse of organic waste and suggests metal limit values (Table S5). ${ }^{31}$

\subsection{Feedback from the questionnaire survey on combustion}

\subsubsection{Input materials}

As shown in Table 2, fuel used in boilers that were subject to the questionnaire was primarily wood, used as wood chips (6 respondents out of 9). Sawmill by-products, peat and other forms of wood (e.g. trays, pallets, wood waste) were used to complement wood chips (3 respondents) or were the main fuels (2 respondents).

To make sure that the boiler operation is going well, operators visually check the fuel supply and remove any undesirable substances (e.g. plastics) that could block the boiler (Table S6). Other quantitative measurements are performed in fuels such as the effective heating value of the fuel (3 respondents out of 9) and contaminants, particularly metal(oid)s ( $\mathrm{Hg}, \mathrm{Cd}, \mathrm{Tl}, \mathrm{As}$, $\mathrm{Pb}, \mathrm{Cr}, \mathrm{Cu}, \mathrm{Ni}, \mathrm{Zn}$ ) (3 respondents) (Table $\mathrm{S} 6$ ). Most of boiler operators using wood chips as a unique fuel coming from the farms production or the boiler vicinity did not measure contaminants, as the origin of the wood was clearly known and there were no reasons to assume 


\section{ACCEPTED MANUSCRIPT}

that they contained contaminants. Boiler operators that measured contaminants in input fuels where those that used wood waste.

When mixtures of different wood origins were used and boiler operators did not have the possibility to check the fuel origin by themselves, the traceability of the wood supply chain was carried out via the specification of input fuels allowed in boilers like in France and Germany or via the SDC services in Sweden (http://www.sdc.se/).

French regulation regarding combustion plants depends on the total rated thermal input and the type of fuels used. ${ }^{32,33}$ These requirements led to 3 categories of boilers, allowed to accept fuels among which products consisting of any vegetable matter from agriculture or forestry that can be used as a fuel for the purpose of recovering its energy content (a), or (b) wastes such as (i) vegetable waste from agriculture and forestry and some biomass classified as wood waste b(v). Depending on the boiler category, requirements regarding metals differ. For instance, in the declaration category, there is no specification concerning metal limit in fuels whereas in the authorization category measurement of maximal metal concentrations in fuels authorized in the permit are set based on data recorded by operator. ${ }^{32,33}$

In Germany, boiler operators conducted their own randomized analyses of input fuel to ensure that their fuel originated from renewable primary products as stipulated in the regulation. ${ }^{21,34}$ Like in France, the German regulation on combustion depends on the total rated thermal input and the type of fuels. If waste wood is used, the boiler falls under the federal immission control ordinance for incineration or co-incineration of waste. ${ }^{35}$ In addition, fuel classes and specifications of solid fuels are set in German standards with the objective to ensure traceability and transparency between seller and buyer and facilitate authority permission 


\section{ACCEPTED MANUSCRIPT}

procedures and reporting. ${ }^{36}$ For instance, typical values, including metal(oid)s, for virgin wood materials are thus listed in these standards as well as normative metal(oid)s for some solid fuels such as graded wood chips.

In Sweden, there is no general binding rules concerning values in biomass. The Swedish regulation on combustion used to fix emission limit values (ELVs) case by case related to the size of the installation and the local situation. From December 2017, the new EU Directive on the limitation of emissions of certain pollutants into the air from medium combustion plants comes into force. ${ }^{37}$ In addition, as in other member states, for the biggest combustion plants $(\geq 50$ MW, the 3 Swedish respondents, Table 1), the EU legislation applies and set ELVs, notably for metals. $^{38,39}$

\subsubsection{Valorization of bottom and fly ashes}

Fly ash constitutes the particulate fraction of the flue gas which is generally more concentrated in metals than the gaseous fraction and the bottom ash. ${ }^{4,5}$ When the boiler is equipped with an efficient cleaning air system (multicyclone, bag filter, electrofilter), fly ash can be trapped to avoid pollutant air emission and subsequently valorized or disposed in discharge. 3 boiler operators out of 9 interviewed separated bottom ash from fly ash (Table S7). Small installations within the respondent panel were not equipped with air emission cleaning system, which did not allow them to recover fly ash. In France and in Germany, where small installations (<0.5 MW) were questioned, bottom ashes were valorized by direct spreading or composting (Table 1). Among those that were equipped with air emission cleaning system (> $0.5 \mathrm{MW})$, some separated ash fractions (3 respondents), whereas some others did not (5 respondents) (Table S7). 


\section{ACCEPTED MANUSCRIPT}

In case of separation, the valorization of the two ash fractions differed from one country to another. The French respondents valorized only bottom ash in agricultural applications (landspreading, composting), fly ash being sent to hazardous or non-hazardous disposal sites. The Swedish respondents valorized both bottom and fly ash fractions in various applications, from fertilizers to forest and construction materials (Table 1).

The French regulation that sets the requirements to spread ash from biomass combustion was recently revised (e.g. ref.32). Land spreading of bottom ash only is allowed. Requirements concerned the bottom ash characterization, the making of a spreading plan and the respect of maximal metal concentrations in bottom ashes and metal load over 10 years. ${ }^{32,33}$ Fly ash and bottom ash have to be stored separately, both ashes having the possibility to be valorized in various materials like concrete or cement or in civil engineering as filling materials, when a trading demand exists..$^{32,33}$

In Germany, wood ash and ash from the combustion of untreated plant biomass can be utilized as an additive to produce inorganic fertilizers under certain conditions. Cyclone filter ash and fly ash are forbidden for this use. Limit values are set on metals and nutrients, the fertilization with wood ashes being regulated in the German fertiliser ordinance. ${ }^{27}$

In Sweden, ash recycling is considered to be an important part of sustainable forestry. Nevertheless, there is no national legislation but only recommendations on utilization of ash in forestry. Swedish recommendations are The Swedish Forestry Agency's view of how ash recycling should be done to meet the requirements provided by the authority regulations to the Swedish Forestry Act and the general rules of consideration in the Swedish Environmental Code. ${ }^{40,41}$ The Agency recommends maximum levels of nutrients and minimum levels of 


\section{ACCEPTED MANUSCRIPT}

potentially toxic elements in ashes that are suitable for the recycling through forest fertilization. A minor exceedance by maximum 5-10\% of the recommended levels for some of the potentially toxic elements may be accepted if it can be assured that the ashes are derived from pure forest fuels without admixture of contaminating fuels. The utilization of ash from other fuels is allowed as long as the ash quality complies with the requirements in these previous recommendations and do not contain harmful substances.

\subsection{Will operators use plants grown on phytomanaged areas in their installation?}

Since the results of the questions focusing on phytotechnologies (Fig. S1) are already available as a report of the GREENLAND project, here the main output is summarized for a scientific audience in Table $3 .^{42}$

The knowledge about phytotechnologies among AD operators was scarce. Only 3 out of 11 were familiar with it, and only 1 could distinguish between phytostabilization and phytoextraction. However, the general acceptance of biomass from phytotechnologies was high under certain prerequisites. Plants cultivated during phytostabilization could be accepted as input in AD facilities if TE content was proved to be low or close to background levels. Contrastingly phytoextracting plants would be accepted as input if TE content was controlled, gas yield was satisfying (no negative impact on equipment and microorganisms) and economic revenues were available. Based on their own perception, several operators mentioned that up to $50 \%$ and $35 \%$ of phytostabilizing and phytoextracting plants, respectively could be introduced in their installations. 


\section{ACCEPTED MANUSCRIPT}

From the AD operators' point of view the use of TE enriched plants could involve more disadvantages than advantages (Table 3).

Among operators and owners of boilers as well as wood suppliers for combustion 4 out of 9 knew about phytotechnologies but no one could distinguish between phytostabilization and phytoextraction. Wood chips were the main source for boilers and in many cases plants originated from areas close to the facility. Plants grown during phytostabilization were considered as biomass ( 1 exception), whereas those from phytoextraction were considered as waste (1 exception and 3 double-minded). This choice was based on the fact, that ashes could not be used unrestricted anymore or boiler equipment could be impaired due to metals. However, in this group the advantages of phytotechnologies, especially aspects of sustainability, were still perceived but yet the perception of disadvantages like (a) the potential need of additional controls, (b) installation modifications and (c) waste treatment assimilation outweighed (Table 3).

\subsection{Taking into account perceptions and regulation: what is feasible?}

The results of the questionnaire survey indicated that plants used in phytostabilization could advantageously be used in the installations of the interviewed operators/actors as a new resource of feedstock or biofuel because they usually show metal concentrations in the range of physiological levels. Among plants that can be cultivated on contaminated land without transferring metals in their harvestable parts, i.e. usable plants for phytostabilization, maize and various other grasses are used for long time in demonstration field sites. ${ }^{3}$ Different cultivars of maize, barley, durum, rye and wheat were then reported to exclude metals, in particular $\mathrm{Cd}$, making them extremely suitable for diverse conversion processes. ${ }^{3}$ For example, maize with its 


\section{ACCEPTED MANUSCRIPT}

high methane yield, the most important parameter for successful anaerobic digestion (AD), is intensively used in AD in Germany and Austria (Table 2). ${ }^{43}$ In addition to maize cultivation on arable land like in Germany, maize could take advantage of its phytostabilizing/excluding trait to be cultivated on metal contaminated site for $\mathrm{AD}$ valuation without metal transfer in emissions and by-products. Other plants or cultivars having both a high methane yield and a low metal transfer rate could be also relevant candidates for $\mathrm{AD}$ on metal contaminated land. ${ }^{44}$ The careful choice of feedstock is essential to get the highest process performance and a high quality digestate. As shown in Table 2, plants are generally co-digestated with other substrates in a range that can reach more than $80 \%$. The study of the regulation of the 4 countries considered in this work showed that the analysis of contaminants in input materials is not compulsory. On the contrary, the analysis of contaminants, in particular metals, are mandatory in the produced digestate when spread on farm land or in the produced compost when the digestate is composted. Metals in both digestate and compost must not exceed metal thresholds stated in national regulation and standards (Table S5). As TE are expected to be concentrated in the digestate when metal-enriched biomass is used as substrate,,${ }^{11,15,42}$ to avoid limitations in the use of digestate and compost, the use of phytostabilizing/phytoexcluding plants could be recommended rather than metal-enriched plants from phytoextraction.

Depending on the country, plants suitable for $\mathrm{AD}$ are regulatory named intermediate crops, energy crops, agricultural waste or product, green waste or product. On the other hand, how the plants grown on contaminated land are regulatory considered is not known (waste or product), this question has not been discussed yet. One reason could be that the amount of plants produced on contaminated sites for remediation purposes or for bioenergy production is so far 


\section{ACCEPTED MANUSCRIPT}

not significant until now, as it is only produced for scientific purposes. ${ }^{42}$ The use of the biomass from contaminated land will be facilitated once the legal framework will be known for this biomass.

Concerning combustion, wood chips from forest and wood-based industries constituted the largest source of solid biomass used as fuel (Table 2). Wood used is very diverse (poplar, willow, alder, coniferous trees, beech, sweet chestnut, birch, oak, ash, hornbeam, eucalyptus, acacia, etc.) and notably depends on country, climate, practices, subsidies, and wood availability. Among wood, several species such as poplar and willow are cultivated in short or very short rotation coppice for combustion purpose as they produce very high biomass yield in few years and easily re-grow after harvest. This long-term tree cultivation is in particular a common practice in Sweden. In contrast to most other trees cited above, poplars and willows are known to accumulate $\mathrm{Cd}$ and $\mathrm{Zn}$ in their leaves and to a lesser extent in wood when they grow on contaminated land. ${ }^{3-5}$ However, metal accumulation strongly depends on cultivar and soil type which make them usable for phytoextraction and phytostabilisation field trials. ${ }^{3}$ From the questionnaire survey, combustion plants (except the smallest) were equipped with air emission cleaning system which might prevent pollutant air emission and thus theoretically allow the use of any tree as fuel in the equipped ones. However, the valorization of ashes was highlighted by the respondents as a very important point to consider in the case of using phytoextracting wood, for which ashes are expected to contain high metal concentrations. ${ }^{4,5,42}$ Indeed, valorization of ashes (bottom ash, fly ash or ash when not separated), which is a common practice in the interviewed countries (see 3.2), could potentially be limited if metal concentrations in ashes do not comply with legal framework. To overcome this limitation, the separation of bottom and fly 


\section{ACCEPTED MANUSCRIPT}

ashes could be recommended in countries where it is not already done for facilitating the re-use

of bottom ashes and to manage fly ashes according to their TE content. ${ }^{4,5,42}$ In addition, the use of cultivars of trees that accumulate metals as little as possible could also be proposed to reduce metal concentrations in ashes. As quoted above, the way of considering the trees (biomass, waste) that grow on contaminated land will guide operators to select the right combustion plant in which this type of fuel could be burnt.

\section{Conclusions}

Through a questionnaire survey performed in 4 European countries, preliminary perceptions of $\mathrm{AD}$ platforms operators and boiler operators/suppliers were gathered to identify the reasons to accept or reject plants grown on phytomanaged areas as feedstock or biofuel in their installations.

For the two valorization options considered in this study, plants used in phytostabilization or phytoexclusion were thought to be less risky and, consequently, benefited from a better theoritical acceptance than those derived from phytoextraction. Thus, AD and combustion seem possible valorization pathways for plants from phytostabilization whereas the possibility that these valorization options are relevant for the plants from phytoextraction is still questionnable. To enhance the reliability of these conclusions, a study with a broader panel and an increased geographic outreach of interviews would be necessary.

To our knowledge, by far, plant biomass on contaminated lands is only produced for scientific purpose to be used in demonstration projects such as in the European project GREENLAND and thus represents a small amount of potential feedstock or biofuel. In the 


\section{ACCEPTED MANUSCRIPT}

future, one can imagine that planting crops on contaminated areas will be part of the RED objective, thus increasing the amount of feedstock and biofuel to be processed. If operators of the biomass conversion processes seem to be ready to accept phytotechnologies biomass in their installations, the question of the legal status of the plant biomass produced on contaminated land (biomass or waste?) is essential to choose the appropriate valorization pathway, and thus, assess the profitability or the cost due to the use of these plants. By far, this question is solved neither at the European level nor at the local/national level.

\section{Acknowledgements}

The authors are grateful for discussion and feedback from French, German, Austrian and Swedish AD platforms and boiler operators/owners. The authors acknowledge ARGE Kompost \& Biogas, Kabsi and the Swedish Environmental Protection Agency (EPA) for helpful information on legal situation in Austria and Sweden. This work was financially supported by the European Commission under the Seventh Framework Programme for Research (FP7-KBBE266124, GREENLAND). 


\section{ACCEPTED MANUSCRIPT}

\section{References}

${ }^{1}$ State of play on the sustainability of solid and gaseous biomass used for electricity, heating and cooling in the EU. Commission staff working document. 2014 Jul 28.

http://ec.europa.eu/energy/sites/ener/files/2014_biomass_state_of_play_.pdf

${ }^{2}$ Directive 2009/28/EC of the European parliament and of the council of 23 April 2009 on the promotion of the use of energy from renewable sources and amending and subsequently repealing Directives 2001/77/EC and 2003/30/EC. OJ L 140, 5.6.2009, p. 16-62. http://eurlex.europa.eu/legal-content/FR/ALL/?uri=CELEX\%3A32009L0028.

${ }^{3}$ Kidd P, Mench M, Álvarez-Lopez V, Bert V, Dimitriou I, Kolbas A, Friesl-Hanl W, Herzig R, Neu S, Müller I, et al. Agronomic practices for improving gentle remediation of trace elementcontaminated soils. Int J Phytorem. 2015; 17: 1005-1037.

${ }^{4}$ Delplanque M, Collet S, Del Gratta F, Schnuriger B, Gaucher R, Robinson B, Bert V. Combustion of Salix used for phytoextraction: the fate of metals and viability of the processes. Biomass Bioenerg 2013; 49: 160-170.

${ }^{5}$ Chalot M, Blaudez D, Rogaume Y, Provent AS, Pascual Ch. Fate of trace elements during the combustion of phytoremediation wood. Environ Sci Technol 2012; 46(24): 13361-9.

${ }^{6}$ EBA Biomethane and Biogas report 2015. Annual statistical report of the European Biogas Association on the European anaerobic digestion industry and markets - http://europeanbiogas.eu.

${ }^{7}$ Wong MH, Cheung YH. Gas production and digestion efficiency of sewage sludge containing elevated toxic metals. Bioresour Technol 1995; 54: 261-8. 


\section{ACCEPTED MANUSCRIPT}

${ }^{8}$ Verma VK, Singh YP, Rai JPN. Biogas production from plant biomass used for phytoremediation of industrial wastes. Bioresour Technol 2007; 98: 1664-9.

${ }^{9}$ Pahl O, Firth A, MacLeod I, Baird J. Anaerobic co-digestion of mechanically biologically treated municipal waste with primary sewage sludge - a feasibility study. Bioresource Technol 2008; 99: 3354-64.

${ }^{10}$ Thewys T, Witters N, Van Slycken SV, Ruttens A, Meers E, Tack FMG, Vangronsveld J. Economic viability of phytoremediation of a cadmium contaminated agricultural area using energy maize. Part I: effect on the farmer's income. Int J Phytorem 2010; 12: 650-62.

${ }^{11}$ Thewys T, Witters N, Meers E, Vangronsveld J. Economic viability of phytoremediation of a cadmium contaminated agricultural area using energy maize. Part II: economics of anaerobic digestion of metal contaminated maize in Belgium. Int J Phytorem 2010; 12: 663-79.

${ }^{12}$ Bert V, Serge Collet, Florence Delgratta, Benoit Schnuriger, Jannis Dimitriou, Rolf Herzig et al. Valorisation of plant biomass harvested at trace element-contaminated sites managed by gentle (phyto)remediation options. Paper presented at: $9^{\text {th }}$ International Phytotechnology Society Conference; 2012 Sept 11-14 ${ }^{\text {th }}$; Hasselt, Belgium.

${ }^{13}$ Van slycken, N. Witters, Meers E, Peene A, Michels E, Adriaensen, Ruttens A, Vangronsveld J, Du Laing G, Van Dael M, Van Passel S, Tack FMG. Environ Pollut 2013;178: 375-80.

${ }^{14}$ Cao Z, Wang S, Wang T, Chang Z, Shen Z, Chen Y. Using contaminated plants involved in phytoremediation for anaerobic digestion. Int J Phytorem 2015; 17(3): 201-7.

${ }^{15}$ Witters N, Mendelsohn RO, Van Slycken SV, Weyens N, Schreurs E, Meers E, Tack F, Carleer R, Vangronsveld J. Phytoremediation, a sustainable remediation technology? Conclusions from a 


\section{ACCEPTED MANUSCRIPT}

case study: I: energy production and carbon dioxide abatement. Biomass Bioenerg 2012; 39: $454-69$.

${ }^{16}$ Wolfe AK, Bjornstad DJ.Why would anyone object? An exploration of social aspects of phytoremediation acceptability. Crit Rev Plant Sci 2002; 21: 429-438.

${ }^{17}$ Décret $n^{\circ} 2009-1341$ du 29 octobre 2009 modifiant la nomenclature des installations classées (NOR: DEVP0908338D).

${ }^{18}$ Quality assurance system for digestate. RAL GZ 245 (digestate): Bundesgütegemeinschaft Kompost e.V. (2016): Gütesicherung Gärprodukt. Verzeichnis zulässiger Ausgangsstoffe. http://www.kompost.de/de/guetesicherung/guetesicherung-gaerprodukt/download/last access: 26.11.2016; RAL GZ 246 (digestate from renewable resources): Bundesgütegemeinschaft Kompost e.V. (2014): Gütesicherung NawaRo Gärprodukt. Verzeichnis zulässiger Ausgangsstoffe. http://www.kompost.de/guetesicherung/guetesicherung-nawarogaerprodukt/download/last access: 26.11.2016.

${ }^{19}$ Erneuerbare-Energien-Gesetz vom 25. Oktober 2008 (BGBl. I S. 2074), das durch Artikel 1 des Gesetzes vom 17. August 2012 (BGBl. I S. 1754) geändert worden ist [last access: 2016 Oct 27]. https://www.clearingstelle-eeg.de/files/EEG2012_juris_120817.pdf

${ }^{20}$ Mast B, Lemmerb A, Oechsnerb H, Reinhardt-Hanischb A, Claupeina W, Graeff-Hönningera S. Methane yield potential of novel perennial biogas crops influenced by harvest date. Indust Crops Products 2014; $58:$ 194-203.

${ }^{21}$ Renewable energy sources act 2014 - Gesetz für den Ausbau erneuerbarer Energien (Erneuerbare-Energien-Gesetz - EEG 2014). http://www.gesetze-iminternet.de/bundesrecht/eeg_2014/gesamt.pdf. 


\section{ACCEPTED MANUSCRIPT}

${ }^{22}$ Österreichischer Biomasseverband 2015. Basisdaten 2015 - Bioenergie. Eigenverlag, p 60.

${ }^{23}$ Arrêté du 8 janvier 1998 fixant les prescriptions techniques applicables aux épandages de boues sur les sols agricoles pris en application du décret nº 97-1133 du 8 décembre 1997 relatif à l'épandage des boues issues du traitement des eaux usées (NOR: ATEE9760538A). http://www.legifrance.gouv.fr/eli/decret/2009/10/29/DEVP0908338D/jo/texte.

${ }^{24}$ French quality standard NF U44-051 (2006) on organic soil improvers - Designations, specifications and marking.

${ }^{25}$ French quality standard NF U44-095 (2002) on organic soil improvers - Composts containing substances essential to agriculture, from water treatment.

${ }^{26}$ Arrêté du 23 juillet 2012 modifiant divers arrêtés relatifs aux installations de traitement de déchets soumises à déclaration au titre de la législation des installations classées pour la protection de l'environnement (DEVP1230759A).

${ }^{27}$ German fertilizer ordinance - Düngemittelverordnung vom 5. Dezember 2012 (BGBl. I S. 2482) https://www.gesetze-im-internet.de/bundesrecht/d_mv_2012/gesamt.pdf (last access: 2710-2016)

${ }^{28}$ German biowaste ordinance - Bioabfallverordnung in der Fassung der Bekanntmachung vom 4. April 2013 (BGB1. I S. 658) https://www.gesetze-im-internet.de/bioabfv/BJNR295500998.html last access: $27-10-2016$

${ }^{29}$ Austrian fertilizer ordinance (Düngemittelverordnung - DMV 2004 (BGBl. 100/2004 igF) https://www.ris.bka.gv.at/ last access: 25.11.2016

${ }^{30}$ Austrian compost ordinance (Kompostverordnung, BGBl. II Nr. 292/2001) https://www.ris.bka.gv.at/ last access: 25.11.2016 


\section{ACCEPTED MANUSCRIPT}

${ }^{31}$ Commission decision of 3 November 2006 establishing revised ecological criteria and the related assessment and verification requirements for the award of the community eco-label to soil improvers, 2006/799/EC 03.11.2006 L325/28. http://eurlex.europa.eu/LexUriServ/LexUriServ.do?uri=OJ:L:2006:325:0028:0034:EN:PDF ${ }^{32}$ Arrêté du 26 août 2013 modifiant l'arrêté du 25 juillet 1997 relatif aux prescriptions générales applicables aux installations classées pour la protection de l'environnement soumises à déclaration sous la rubrique $\mathrm{n}^{\circ} 2910$ (Combustion). http://www.legifrance.gouv.fr/eli/arrete/2013/8/26/DEVP1300524A/jo/texte.

${ }^{33}$ Arrêté du 26 août 2013 relatif aux installations de combustion d'une puissance supérieure ou égale à 20 MW soumises à autorisation au titre de la rubrique 2910 et de la rubrique 2931. http://www.legifrance.gouv.fr/eli/arrete/2013/8/26/DEVP1300515A/jo/texte.

${ }^{34}$ German biomass ordinance - Biomasseverordnung vom 21. Juni 2001 (BGB1. I S. 1234), die durch Artikel 8 des Gesetzes vom 13. Oktober 2016 (BGBl. I S. 2258) geändert worden ist https://www.gesetze-im-internet.de/biomassev/BJNR123400001.html (last access: 27-102016) ${ }^{35}$ Immission control ordinance 2010 - Erste Verordnung zur Durchführung des BundesImmissionsschutzgesetzes (Verordnung über kleine und mittlere Feuerungsanlagen - BImSchV). http://www.gesetze-im-internet.de/bundesrecht/bimschv_1_2010/gesamt.pdf ${ }^{36}$ German standards DIN EN ISO 17225(1-6):2014-09. Solid biofuels - Fuel specifications and classes - Part 1: General requirements; Part 2: Graded wood pellets; Part 3: Graded wood briquettes; Part 4: Graded wood chips; Graded firewood; Part 6: Graded non-woody pellets. 


\section{ACCEPTED MANUSCRIPT}

${ }^{37}$ EU Directive 2015/2193 of the European Parliament and of the Council of 25 November 2015 on the limitation of emissions of certain pollutants into the air from medium combustion plants. Official Journal of the European Union, 28.11.2015.

${ }^{38}$ Directive 2010/75/EU of the European Parliament and of the Council of 24 November 2010 on industrial emissions (integrated pollution prevention and control). OJ L 334, 17.12.2010, p. 1711.

${ }^{39}$ Directive 2015/2193/EU of the European Parliament and of the Council of 25 November 2015 on the limitation of emissions of certain pollutants into the air from medium combustion plants. OJ L 313, 28.11.2015, p. 1-19.

${ }^{40}$ Swedish Forestry Act (SFS1979:429). Swedish statute book. The Swedish Government Office.1979-06-07.

${ }^{41}$ Swedish Environmental Code (1998:808) ). Swedish statute book. The Swedish Government Office. 1998-06-11.

${ }^{42}$ Bert V, Janssen J, Gaucher R. GREENLAND - Gentle remediation of traceelement contaminated land. Best practice guidance for practical application of gentle remediation options (GRO): Appendices/technical reference sheets. Appendix 3: Safe biomass usage ; 2014. p17-27. http://www.greenland-project.eu/downloads/Greenland\%20bestpractice\%20guide\%20appendices.pdf

${ }^{43}$ Hermann A, Rath J. Biogas production from maize: Current state, challenges and prospects. 1. Methane yield potential. Bioenerg Res 2012; 5(4): 1027-42. 


\section{ACCEPTED MANUSCRIPT}

${ }^{44}$ Murphy J, Braun R, Weiland P, Wellinger A. Biogas from crop digestion. IEA Task 37

Brochure, International Energy Agency, Paris, France. 2011. http://www.iea-

biogas.net/files/daten-redaktion/download/publi-task37/Update_Energy_crop_2011.pdf 


\section{ACCEPTED MANUSCRIPT}

Table 1. Main characteristics of $\mathrm{AD}(\mathrm{A})$ and boiler (B) installations and respective input materials. Size of digester corresponds to French limit values described in the French "Nomenclature" of classified installations [15] ( $\mathrm{S}=$ small: below 11,000 tons year ${ }^{-1}, \mathrm{M}=$ medium: 11,000 to 22,000 tons year ${ }^{-1}, \mathrm{~L}=$ large $:>22,000$ tons year $\left.^{-1}\right)$. Amount of input materials is in tons year $^{-1}$.

\begin{tabular}{|c|c|c|c|c|c|c|}
\hline A - & Installati & & Input ms & rials & Valuation & \\
\hline & Type & Size & Amount & Type & Biogas & Digestate \\
\hline $\begin{array}{l}\text { FR } \\
1\end{array}$ & Farm & $\mathrm{S}$ & 10,000 & $\begin{array}{l}\text { Liquid/solid manure, } \\
\text { agricultural waste, } \\
\text { cooking/flotation fats, cooki1 } \\
\text { liquid, crop/vegetable waste } \\
\text { intermediate crops }\end{array}$ & $\begin{array}{l}\text { Co-generation, } \\
\text { electricity }\end{array}$ & $\begin{array}{l}\text { Direct } \\
\text { spreading }\end{array}$ \\
\hline $\begin{array}{l}\text { FR } \\
2\end{array}$ & $\begin{array}{l}\text { Compan } \\
\text { y }\end{array}$ & $\mathrm{L}$ & 58,000 & $\begin{array}{l}\text { Solid waste, green waste, } \\
\text { food waste, fats }\end{array}$ & $\begin{array}{l}\text { Co-generation, } \\
\text { electricity }\end{array}$ & Compost \\
\hline $\begin{array}{l}\text { FR } \\
3\end{array}$ & $\begin{array}{l}\text { Municip } \\
\text { al } \\
\text { facility }\end{array}$ & $\mathrm{L}$ & 42,000 & $\begin{array}{l}\text { Solid manure, green waste, } \\
\text { food industry/restaurant } \\
\text { waste, biowaste (organic } \\
\text { fraction of municipal solid } \\
\text { waste) }\end{array}$ & $\begin{array}{l}\text { Co-generation, } \\
\text { biofuel, gas grid } \\
\text { injection }\end{array}$ & Compost \\
\hline $\begin{array}{l}\text { FR } \\
4\end{array}$ & Farm & M & 12,500 & $\begin{array}{l}\text { Food industry waste, } \\
\text { liquid/solid manure, whey, } \\
\text { agriculture waste, } \\
\text { intermediate crops }\end{array}$ & $\begin{array}{l}\text { Gas grid } \\
\text { injection }\end{array}$ & $\begin{array}{l}\text { Direct } \\
\text { spreading }\end{array}$ \\
\hline $\begin{array}{l}\text { FR } \\
5\end{array}$ & Farm & S & 2000 & Solid manure, green waste & $\begin{array}{l}\text { Co-generation, } \\
\text { electricity, }\end{array}$ & $\begin{array}{l}\text { Direct } \\
\text { spreading, } \\
\text { compost }\end{array}$ \\
\hline $\begin{array}{l}\mathrm{GE} \\
1\end{array}$ & $\begin{array}{l}\text { Agricult } \\
\text { ural } \\
\text { cooperati } \\
\text { ve }\end{array}$ & $\mathrm{L}$ & 48,000 & Slurry, agricultural waste & Co-generation & $\begin{array}{l}\text { Direct } \\
\text { spreading }\end{array}$ \\
\hline $\begin{array}{l}\mathrm{GE} \\
2\end{array}$ & $\begin{array}{l}\text { Municip } \\
\text { al } \\
\text { facility }\end{array}$ & $\mathrm{L}$ & 50,000 & $\begin{array}{l}\text { Slurry, green waste, } \\
\text { agricultural waste }\end{array}$ & $\begin{array}{l}\text { Gas grid } \\
\text { injection }\end{array}$ & $\begin{array}{l}\text { Direct } \\
\text { spreading }\end{array}$ \\
\hline $\begin{array}{l}\text { GE } \\
3\end{array}$ & $\begin{array}{l}\text { Municip } \\
\text { al } \\
\text { facility }\end{array}$ & S & 10,000 & Slurry, agricultural waste & Co-generation & $\begin{array}{l}\text { Direct } \\
\text { spreading }\end{array}$ \\
\hline GE & Agricult & $S$ & 2450 & Slurry, solid manure, & Co-generation & Direct \\
\hline
\end{tabular}




\section{ACCEPTED MANUSCRIPT}

agricultural waste, green waste spreading

$\begin{array}{cc}\text { Co-generation } & \begin{array}{c}\text { Direct } \\ \text { spreading }\end{array}\end{array}$

Co-generation Direct spreading
4 ural cooperati

\begin{tabular}{|c|c|c|c|}
\hline $\begin{array}{l}\text { AT } \\
1\end{array}$ & Farm & $\mathrm{S}$ & 6500 \\
\hline $\begin{array}{l}\text { AT } \\
2\end{array}$ & Farm & S & 2400 \\
\hline B - & \multicolumn{2}{|c|}{ Installation } & Input \\
\hline & Type & NTP* & Amov \\
\hline FR & Compan & 0.2 to & 330,00 \\
\hline 1 & $\mathrm{y}$ & 50 & $\begin{array}{l}0 \text { to } \\
500,00 \\
0\end{array}$ \\
\hline
\end{tabular}

FR Municip $10 \quad 13,000$

2 al

compan

y Liquid manure, green
products, agricultural products

Liquid manure, green

products, agricultural products

Liquid manure, green rials Type Wood, bark, miscanthus, sorghum, hemp, switchgrass

Wood

$3 \quad 10$

FR Municip $1.6 \quad 2,200 \quad$ Wood

4 al

compan

\begin{tabular}{lll}
\multicolumn{1}{c}{$y$} & \\
\hline GE & Agricult & 0 \\
1 & ural & 5 \\
& cooperat & \\
& ive &
\end{tabular}

GE
Wood

0.1 to 40,000 Wood

5

40

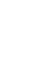

Heat

Valuation

Gas

Heat, electricity Composti Ashes
Composti
ng, waste discharge

Composti

ng, waste discharge

Heat

Composti ng, waste discharge Direct spreading, waste discharge Direct spreading Heat

Heat

Heat

Wood

Heat

Wood, peat

Heat

Waste discharge Direct spreading, constructi on materials

S Municip $80 \quad 160,000 \quad$ Wood

Heat Direct W al

2 compan

y

S Municip $104 \quad 160,000 \quad$ Wood, bark, peat W al

Heat spreading

3 compan

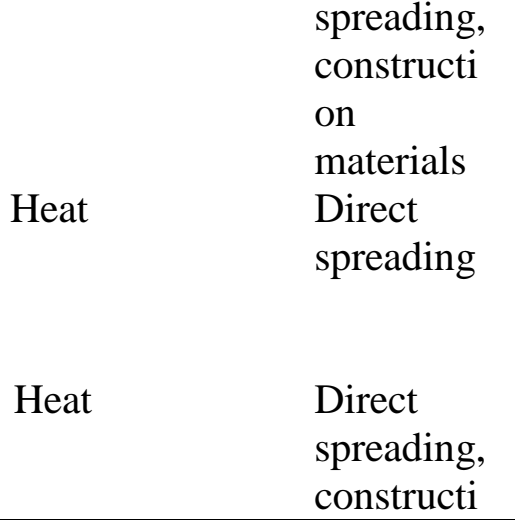




\section{ACCEPTED MANUSCRIPT}

$\mathrm{y}$

on

materials

*Nominal thermal power, expressed in MW

Table 2. Type of plants used by AD operators and fuels used in combustion plants.

\begin{tabular}{|c|c|c|}
\hline & AD & Combustion \\
\hline \multirow[t]{2}{*}{ FR1 } & Rye, sunflower, sorghum* & $\begin{array}{l}\text { Wood chips }(80-85 \%), \text { pallets/trays }(13- \\
18 \%), \text { sawmill by-products } \\
(1-2 \%)\end{array}$ \\
\hline & Vegetables, cereal wastes & \\
\hline FR2 & Grass, trees, shrubs & $\begin{array}{l}\text { Wood chips }(30 \%) \text {, pallets/trays/wood } \\
\text { waste }(56 \%) \text {, sawmill by-products }(14 \%)\end{array}$ \\
\hline FR3 & Wood residues, lawn mowing & $\begin{array}{l}\text { Wood chips }(50-100 \%) \text {, pallets/trays }(35- \\
40 \%) \text {, sawmill by-products }(10-15 \%)\end{array}$ \\
\hline FR4 & $\begin{array}{l}\text { Biomass rye, sorghum, ray-grass, naked } \\
\text { oat, maize* } \\
\text { Agricultural waste }\end{array}$ & Wood chips $(100 \%)$ \\
\hline FR5 & Lawn mowing, woody residues & - \\
\hline GE1 & Maize silage, lawn mowing, cereals & Wood chips $(100 \%)$ \\
\hline GE2 & Maize silage, lawn mowing & Wood chips $(100 \%)$ \\
\hline GE3 & Maize silage & - \\
\hline GE4 & Maize silage, grasses, cereals & - \\
\hline AT1 & $\begin{array}{l}\text { Maize silage, lawn mowing, clover, alfafa, } \\
\text { Dactylis glomerata }\end{array}$ & - \\
\hline AT2 & Maize silage, lawn mowing & - \\
\hline SW1 & - & $\begin{array}{l}\text { Wood chips }(10 \%) \text {, pallets/trays/sawmill by } \\
\text { products }(70 \%) \text {, peat }(20 \%)\end{array}$ \\
\hline SW2 & - & $\begin{array}{l}\text { Wood chips, pallets/trays/wood } \\
\text { waste/recycled wood, sawmill by-products }\end{array}$ \\
\hline SW3 & - & $\begin{array}{l}\text { Wood chips }(60 \%) \text {, peat }(8 \%) \text {, sawmill by- } \\
\text { products }(12 \%) \text {, bark }(20 \%)\end{array}$ \\
\hline
\end{tabular}

* intermediate crops 


\section{ACCEPTED MANUSCRIPT}

Table 3. Knowledge of phytotechnologies, conditions of acceptance of phytoremediating plants in $\mathrm{AD}(\mathrm{A})$ and boilers (B). Advantages are: Providing source diversification (1), local biomass source increase (2), non food landing competition (3), sustainable development suitability (4), economical interest (5). Disadvantages are: additional control (1), installation modification (2), unsustainable development (3), no economical interest (4), waste treatment assimilation (5).

\begin{tabular}{llllll} 
A - & $\begin{array}{l}\text { Phytotechnologies } \\
\text { knowledge }\end{array}$ & $\begin{array}{l}\text { Phytostabilising } \\
\text { plants use }\end{array}$ & $\begin{array}{l}\text { Phytoextracting } \\
\text { plants use }\end{array}$ & Advantages & Disadvantages \\
\hline FR1 & Yes & Yes & Yes & $(1),(2)$ & $(1)$ \\
FR2 & No & Yes & No & $(3)$ & $(1),(3),(4),(5)$ \\
FR3 & Yes & Yes & No & $(1),(3),(4),(5)$ & $(1),(3),(4),(5)$ \\
FR4 & Yes & Yes & Yes & $(4),(5)$ & $(1),(5)$ \\
FR5 & No & Yes & Yes & $(1),(2),(3),(4),(5)$ & $(1)$ \\
\hline GE1 & No & Yes & Yes & $(2),(3),(4)$ & $(5)$ \\
GE2 & No & Yes & Yes & $(1)$ & $(1),(2)$ \\
GE3 & No & Yes & Yes & $(1)$ & $(1),(2)$ \\
GE4 & No & Yes & Yes & $(1),(2)$ & $(1),(5)$ \\
\hline AT1 & No & Yes & Yes & $(2),(3),(4),(5)$ & $(1),(5)$ \\
AT2 & No & Yes & Yes & $(2),(3),(4),(5)$ & $(1),(5)$ \\
\hline B - & Phytotechnologies & Phytostabilising & Phytoextracting & Advantages & Disadvantages \\
& knowledge & plants status & plants status & & \\
\hline FR1 & Yes & Biomass & Biomass or waste & $(1),(3),(5)$ & $(1),(2),(4),(5)$ \\
FR2 & Yes & Biomass & Waste & $(1),(3),(4),(5)$ & $(1),(2),(4),(5)$ \\
FR3 & No & Biomass & Waste & $(1),(2),(3),(4),(5)$ & $(1),(2),(5)$ \\
FR4 & Yes & Biomass & Waste & $(1),(2),(3),(4),(5)$ & $(1),(2)$ \\
\hline GE1 & No & Biomass & Biomass or waste & $(1),(2),(4)$ & $(1),(2),(5)$ \\
GE2 & No & Biomass & Biomass & $(1),(2),(3),(4)$ & none \\
\hline SW1 & No & Waste & Waste & $(1),(4)$ & $(3)$ \\
SW2 & Yes & Biomass & Waste & $4),(5)$ & $(1),(2),(4),(5)$ \\
SW3 & No & Biomass & Biomass or waste & $(5)$ & $(1),(2),(4)$ \\
\hline
\end{tabular}

